\title{
Calcium-sensing receptor in GtoPdb v.2021.3
}

Daniel Bikle ${ }^{1}$, Hans Bräuner-Osborne ${ }^{2}$, Edward M. Brown ${ }^{3}$, Wenhan Chang ${ }^{1}$, Arthur Conigrave ${ }^{4}$, Fadil Hannan ${ }^{5}$, Katie Leach ${ }^{6}$, Daniela Riccardi ${ }^{7}$, Dolores Shoback ${ }^{1}$, Donald T. Ward ${ }^{8}$ and Polina Yarova $^{7}$

1. University of California San Francisco, USA

2. University of Copenhagen, Denmark

3. Harvard University, USA

4. University of Sydney, Australia

5. Royal Liverpool University Hospital, UK

6. Monash University, Australia

7. Cardiff University, UK

8. University of Manchester, UK

\begin{abstract}
The calcium-sensing receptor (CaS, provisional nomenclature as recommended by NC-IUPHAR [47] and subsequently updated [77]) responds to multiple endogenous ligands, including extracellular calcium and other divalent/trivalent cations, polyamines and polycationic peptides, Lamino acids (particularly L-Trp and L-Phe), glutathione and various peptide analogues, ionic strength and extracellular $\mathrm{pH}$ (reviewed in [78]). While divalent/trivalent cations, polyamines and polycations are CaS receptor agonists [14, 110], L-amino acids, glutamyl peptides, ionic strength and $\mathrm{pH}$ are allosteric modulators of agonist function [36, 47, 61, 108, 109]. Indeed, L-amino acids have been identified as "co-agonists", with both concomitant calcium and L-amino acid binding required for full receptor activation $[148,54]$. The sensitivity of the CaS receptor to primary agonists is increased by elevated extracellular $\mathrm{pH}$ [18] or decreased extracellular ionic strength [109]. This receptor bears no sequence or structural relation to the plant calcium receptor, also called CaS.
\end{abstract}

\section{Contents}

This is a citation summary for Calcium-sensing receptor in the Guide to Pharmacology database (GtoPdb). It exists purely as an adjunct to the database to facilitate the recognition of citations to and from the database by citation analyzers. Readers will almost certainly want to visit the relevant sections of the database which are given here under database links.

GtoPdb is an expert-driven guide to pharmacological targets and the substances that act on them. GtoPdb is a reference work which is most usefully represented as an on-line database. As in any publication this work should be appropriately cited, and the papers it cites should also be recognized. This document provides a citation for the relevant parts of the database, and also provides a reference list for the research cited by those parts. For further details see [17].

Please note that the database version for the citations given in GtoPdb are to the most recent preceding version in which the family or its subfamilies and targets were substantially changed. The links below are to the current version. If you need to consult the cited version, rather than the most recent version, please contact the GtoPdb curators.

\section{Database links}

Calcium-sensing receptor

https://www.guidetopharmacology.org/GRAC/FamilyDisplayForward?familyId=12

Introduction to Calcium-sensing receptor

https://www.guidetopharmacology.org/GRAC/FamilyIntroductionForward?familyId=12

Receptors

CaS receptor

https://www.guidetopharmacology.org/GRAC/ObjectDisplayForward?objectId=54 


\section{References}

1. Adams GB, Chabner KT, Alley IR, Olson DP, Szczepiorkowski ZM, Poznansky MC, Kos CH, Pollak MR, Brown EM and Scadden DT. (2006) Stem cell engraftment at the endosteal niche is specified by the calcium-sensing receptor. Nature 439: 599-603 [PMID:16382241]

2. Aslanova UF, Morimoto T, Farajov EI, Kumagai N, Nishino M, Sugawara N, Ohsaga A, Maruyama Y, Tsuchiya S and Takahashi S et al.. (2006) Chloride-dependent intracellular pH regulation via extracellular calcium-sensing receptor in the medullary thick ascending limb of the mouse kidney. Tohoku J Exp Med 210: 291-300 [PMID:17146194]

3. Ba J, Brown D and Friedman PA. (2003) Calcium-sensing receptor regulation of PTH-inhibitable proximal tubule phosphate transport. Am J Physiol Renal Physiol 285: F1233-43 [PMID:12952858]

4. Bai M, Quinn S, Trivedi S, Kifor O, Pearce SH, Pollak MR, Krapcho K, Hebert SC and Brown EM. (1996) Expression and characterization of inactivating and activating mutations in the human Ca2+o-sensing receptor. J Biol Chem 271: 19537-45 [PMID:8702647]

5. Balan G, Bauman J, Bhattacharya S, Castrodad M, Healy DR, Herr M, Humphries P, Jennings S, Kalgutkar AS and Kapinos B et al.. (2009) The discovery of novel calcium sensing receptor negative allosteric modulators. Bioorg Med Chem Lett 19: 3328-32 [PMID:19442519]

6. Bandyopadhyay S, Jeong KH, Hansen JT, Vassilev PM, Brown EM and Chattopadhyay N. (2007) Calcium-sensing receptor stimulates secretion of an interferon-gamma-induced monokine (CXCL10) and monocyte chemoattractant protein-3 in immortalized GnRH neurons. J Neurosci Res 85: 882-95 [PMID:17285630]

7. Blankenship KA, Williams JJ, Lawrence MS, McLeish KR, Dean WL and Arthur JM. (2001) The calcium-sensing receptor regulates calcium absorption in MDCK cells by inhibition of PMCA. Am J Physiol Renal Physiol 280: F815-22 [PMID:11292623]

8. Bradbury RA, Cropley J, Kifor O, Lovicu FJ, de Iongh RU, Kable E, Brown EM, Seely EW, Peat $\mathrm{BB}$ and Conigrave AD. (2002) Localization of the extracellular $\mathrm{Ca}(2+)$-sensing receptor in the human placenta. Placenta 23: 192-200 [PMID:11945086]

9. Bradbury RA, Sunn KL, Crossley M, Bai M, Brown EM, Delbridge L and Conigrave AD. (1998) Expression of the parathyroid $\mathrm{Ca}(2+)$-sensing receptor in cytotrophoblasts from human term placenta. J Endocrinol 156: 425-30 [PMID:9582498]

10. Broadhead GK, Mun HC, Avlani VA, Jourdon O, Church WB, Christopoulos A, Delbridge L and Conigrave AD. (2011) Allosteric modulation of the calcium-sensing receptor by gamma-glutamyl peptides: inhibition of PTH secretion, suppression of intracellular cAMP levels, and a common mechanism of action with L-amino acids. J Biol Chem 286: 8786-97 [PMID:21187282]

11. Brown AJ, Zhong M, Finch J, Ritter C, McCracken R, Morrissey J and Slatopolsky E. (1996) Rat calcium-sensing receptor is regulated by vitamin D but not by calcium. Am J Physiol 270: F45460 [PMID:8780248]

12. Brown EM and Chen CJ. (1989) Calcium, magnesium and the control of PTH secretion. Bone Miner 5: 249-57 [PMID:2655774]

13. Brown EM, Fuleihan G el-H, Chen CJ and Kifor O. (1990) A comparison of the effects of divalent and trivalent cations on parathyroid hormone release, 3',5'-cyclic-adenosine monophosphate accumulation, and the levels of inositol phosphates in bovine parathyroid cells. Endocrinology 127: 1064-71 [PMID:2167204]

14. Brown EM, Gamba G, Riccardi D, Lombardi M, Butters R, Kifor O, Sun A, Hediger MA, Lytton J and Hebert SC. (1993) Cloning and characterization of an extracellular $\mathrm{Ca}(2+)$-sensing receptor from bovine parathyroid. Nature 366: 575-80 [PMID:8255296]

15. Brown EM, Katz C, Butters R and Kifor O. (1991) Polyarginine, polylysine, and protamine mimic the effects of high extracellular calcium concentrations on dispersed bovine parathyroid cells. $J$ Bone Miner Res 6: 1217-25 [PMID:1666808]

16. Bräuner-Osborne H, Jensen AA, Sheppard PO, O'Hara P and Krogsgaard-Larsen P. (1999) The agonist-binding domain of the calcium-sensing receptor is located at the amino-terminal domain. J Biol Chem 274: 18382-6 [PMID:10373443]

17. Buneman P, Christie G, Davies JA, Dimitrellou R, Harding SD, Pawson AJ, Sharman JL and Wu Y. (2020) Why data citation isn't working, and what to do about it Database 2020 [PMID:32367113]

18. Campion KL, McCormick WD, Warwicker J, Khayat ME, Atkinson-Dell R, Steward MC, Delbridge LW, Mun HC, Conigrave AD and Ward DT. (2015) Pathophysiologic Changes in Extracellular pH Modulate Parathyroid Calcium-Sensing Receptor Activity and Secretion via a HistidineIndependent Mechanism. J Am Soc Nephrol 26: 2163-71 [PMID:25556167]

19. Canaff L, Petit JL, Kisiel M, Watson PH, Gascon-Barré M and Hendy GN. (2001) Extracellular calcium-sensing receptor is expressed in rat hepatocytes. coupling to intracellular calcium mobilization and stimulation of bile flow. J Biol Chem 276: 4070-9 [PMID:11071898]

20. Centeno PP, Herberger A, Mun HC, Tu C, Nemeth EF, Chang W, Conigrave AD and Ward DT. (2019) Phosphate acts directly on the calcium-sensing receptor to stimulate parathyroid 
hormone secretion. Nat Commun 10: 4693 [PMID:31619668]

21. Chang W, Pratt S, Chen TH, Nemeth E, Huang Z and Shoback D. (1998) Coupling of calcium receptors to inositol phosphate and cyclic AMP generation in mammalian cells and Xenopus laevis oocytes and immunodetection of receptor protein by region-specific antipeptide antisera. $J$ Bone Miner Res 13: 570-580 [PMID:9556057]

22. Chang W, Tu C, Chen TH, Bikle D and Shoback D. (2008) The extracellular calcium-sensing receptor (CaSR) is a critical modulator of skeletal development. Sci Signal 1: ra1 [PMID:18765830]

23. Chang W, Tu C, Chen TH, Komuves L, Oda Y, Pratt SA, Miller S and Shoback D. (1999) Expression and signal transduction of calcium-sensing receptors in cartilage and bone. Endocrinology 140: 5883-93 [PMID:10579354]

24. Chang W, Tu C, Cheng Z, Rodriguez L, Chen TH, Gassmann M, Bettler B, Margeta M, Jan LY and Shoback D. (2007) Complex formation with the Type B gamma-aminobutyric acid receptor affects the expression and signal transduction of the extracellular calcium-sensing receptor. Studies with HEK-293 cells and neurons. J Biol Chem 282: 25030-40 [PMID:17591780]

25. Chattopadhyay N, Cheng I, Rogers K, Riccardi D, Hall A, Diaz R, Hebert SC, Soybel DI and Brown EM. (1998) Identification and localization of extracellular $\mathrm{Ca}(2+)$-sensing receptor in rat intestine. Am J Physiol 274: G122-30 [PMID:9458781]

26. Chattopadhyay N, Evliyaoglu C, Heese O, Carroll R, Sanders J, Black P and Brown EM. (2000) Regulation of secretion of PTHrP by $\mathrm{Ca}(2+)$-sensing receptor in human astrocytes, astrocytomas, and meningiomas. Am J Physiol, Cell Physiol 279: C691-9 [PMID:10942719]

27. Chattopadhyay N, Yano S, Tfelt-Hansen J, Rooney P, Kanuparthi D, Bandyopadhyay S, Ren X, Terwilliger E and Brown EM. (2004) Mitogenic action of calcium-sensing receptor on rat calvarial osteoblasts. Endocrinology 145: 3451-62 [PMID:15084499]

28. Chattopadhyay N, Ye C, Singh DP, Kifor O, Vassilev PM, Shinohara T, Chylack Jr LT and Brown EM. (1997) Expression of extracellular calcium-sensing receptor by human lens epithelial cells. Biochem Biophys Res Commun 233: 801-5 [PMID:9168937]

29. Chattopadhyay N, Ye C, Yamaguchi T, Nakai M, Kifor O, Vassilev PM, Nishimura RN and Brown EM. (1999) The extracellular calcium-sensing receptor is expressed in rat microglia and modulates an outward K+ channel. J Neurochem 72: 1915-22 [PMID:10217268]

30. Chattopadhyay N, Ye CP, Yamaguchi T, Kifor O, Vassilev PM, Nishimura R and Brown EM. (1998) Extracellular calcium-sensing receptor in rat oligodendrocytes: expression and potential role in regulation of cellular proliferation and an outward K+ channel. Glia 24: 449-58 [PMID:9814825]

31. Chen CJ, Barnett JV, Congo DA and Brown EM. (1989) Divalent cations suppress 3',5'-adenosine monophosphate accumulation by stimulating a pertussis toxin-sensitive guanine nucleotidebinding protein in cultured bovine parathyroid cells. Endocrinology 124: 233-9 [PMID:2462488]

32. Cheng I, Klingensmith ME, Chattopadhyay N, Kifor O, Butters RR, Soybel DI and Brown EM. (1998) Identification and localization of the extracellular calcium-sensing receptor in human breast. J Clin Endocrinol Metab 83: 703-7 [PMID:9467597]

33. Cheng I, Qureshi I, Chattopadhyay N, Qureshi A, Butters RR, Hall AE, Cima RR, Rogers KV, Hebert SC and Geibel JP et al.. (1999) Expression of an extracellular calcium-sensing receptor in rat stomach. Gastroenterology 116: 118-26 [PMID:9869609]

34. Cheng Z, Tu C, Rodriguez L, Chen TH, Dvorak MM, Margeta M, Gassmann M, Bettler B, Shoback D and Chang W. (2007) Type B gamma-aminobutyric acid receptors modulate the function of the extracellular Ca2+-sensing receptor and cell differentiation in murine growth plate chondrocytes. Endocrinology 148: 4984-92 [PMID:17615148]

35. Conigrave AD, Mun HC, Delbridge L, Quinn SJ, Wilkinson M and Brown EM. (2004) L-amino acids regulate parathyroid hormone secretion. J Biol Chem 279: 38151-9 [PMID:15234970]

36. Conigrave AD, Quinn SJ and Brown EM. (2000) L-amino acid sensing by the extracellular Ca2+sensing receptor. Proc Natl Acad Sci USA 97: 4814-9 [PMID:10781086]

37. Cook AE, Mistry SN, Gregory KJ, Furness SG, Sexton PM, Scammells PJ, Conigrave AD, Christopoulos A and Leach K. (2015) Biased allosteric modulation at the CaS receptor engendered by structurally diverse calcimimetics. Br J Pharmacol 172: 185-200 [PMID:25220431]

38. Dauban P, Ferry S, Faure H, Ruat M and Dodd RH. (2000) N1-Arylsulfonyl-N2-(1-aryl)ethyl-3phenylpropane-1,2-diamines as novel calcimimetics acting on the calcium sensing receptor. Bioorg Med Chem Lett 10: 2001-4 [PMID:10987436]

39. Davey AE, Leach K, Valant C, Conigrave AD, Sexton PM and Christopoulos A. (2012) Positive and negative allosteric modulators promote biased signaling at the calcium-sensing receptor. Endocrinology 153: 1232-41 [PMID:22210744]

40. de Jesus Ferreira MC, Héliès-Toussaint C, Imbert-Teboul M, Bailly C, Verbavatz JM, Bellanger AC and Chabardès D. (1998) Co-expression of a Ca2+-inhibitable adenylyl cyclase and of a $\mathrm{Ca} 2+-$ sensing receptor in the cortical thick ascending limb cell of the rat kidney. Inhibition of hormone-dependent cAMP accumulation by extracellular Ca2+. J Biol Chem 273: 15192-202 
[PMID:9614133]

41. Desfleurs E, Wittner M, Pajaud S, Nitschke R, Rajerison RM and Di Stefano A. (1999) The Ca2+sensing receptor in the rabbit cortical thick ascending limb (CTAL) is functionally not coupled to phospholipase C. Pflugers Arch 437: 716-23 [PMID:10087149]

42. Didiuk MT, Griffith DA, Benbow JW, Liu KK, Walker DP, Bi FC, Morris J, Guzman-Perez A, Gao H and Bechle BM et al.. (2009) Short-acting 5-(trifluoromethyl)pyrido[4,3-d]pyrimidin-4(3H)-one derivatives as orally-active calcium-sensing receptor antagonists. Bioorg Med Chem Lett 19: 4555-9 [PMID:19625189]

43. Dvorak MM, Siddiqua A, Ward DT, Carter DH, Dallas SL, Nemeth EF and Riccardi D. (2004) Physiological changes in extracellular calcium concentration directly control osteoblast function in the absence of calciotropic hormones. Proc Natl Acad Sci USA 101: 5140-5 [PMID:15051872]

44. Emanuel RL, Adler GK, Kifor O, Quinn SJ, Fuller F, Krapcho K and Brown EM. (1996) Calciumsensing receptor expression and regulation by extracellular calcium in the AtT-20 pituitary cell line. Mol Endocrinol 10: 555-65 [PMID:8732686]

45. Fatherazi S, Belton CM, Cai S, Zarif S, Goodwin PC, Lamont RJ and Izutsu KT. (2004) Calcium receptor message, expression and function decrease in differentiating keratinocytes. Pflugers Arch 448: 93-104 [PMID:14770313]

46. Ferry S, Chatel B, Dodd RH, Lair C, Gully D, Maffrand JP and Ruat M. (1997) Effects of divalent cations and of a calcimimetic on adrenocorticotropic hormone release in pituitary tumor cells. Biochem Biophys Res Commun 238: 866-73 [PMID:9325183]

47. Foord SM, Bonner TI, Neubig RR, Rosser EM, Pin JP, Davenport AP, Spedding M and Harmar AJ. (2005) International Union of Pharmacology. XLVI. G protein-coupled receptor list. Pharmacol Rev 57: 279-88 [PMID:15914470]

48. Freichel M, Zink-Lorenz A, Holloschi A, Hafner M, Flockerzi V and Raue F. (1996) Expression of a calcium-sensing receptor in a human medullary thyroid carcinoma cell line and its contribution to calcitonin secretion. Endocrinology 137: 3842-8 [PMID:8756555]

49. Fudge NJ and Kovacs CS. (2004) Physiological studies in heterozygous calcium sensing receptor (CaSR) gene-ablated mice confirm that the CaSR regulates calcitonin release in vivo. BMC Physiol 4: 5 [PMID:15099400]

50. Gama L, Wilt SG and Breitwieser GE. (2001) Heterodimerization of calcium sensing receptors with metabotropic glutamate receptors in neurons. J Biol Chem 276: 39053-9 [PMID:11489900]

51. Garrett JE, Tamir H, Kifor O, Simin RT, Rogers KV, Mithal A, Gagel RF and Brown EM. (1995) Calcitonin-secreting cells of the thyroid express an extracellular calcium receptor gene. Endocrinology 136: 5202-11 [PMID:7588259]

52. Gavai AV, Vaz RJ, Mikkilineni AB, Roberge JY, Liu Y, Lawrence RM, Corte JR, Yang W, Bednarz $\mathrm{M}$ and Dickson Jr JK et al.. (2005) Discovery of novel 1-arylmethyl pyrrolidin-2-yl ethanol amines as calcium-sensing receptor antagonists. Bioorg Med Chem Lett 15: 5478-82 [PMID:16216508]

53. Geibel J, Sritharan K, Geibel R, Geibel P, Persing JS, Seeger A, Roepke TK, Deichstetter M, Prinz $\mathrm{C}$ and Cheng SX et al.. (2006) Calcium-sensing receptor abrogates secretagogue- induced increases in intestinal net fluid secretion by enhancing cyclic nucleotide destruction. Proc Natl Acad Sci USA 103: 9390-7 [PMID:16760252]

54. Geng Y, Mosyak L, Kurinov I, Zuo H, Sturchler E, Cheng TC, Subramanyam P, Brown AP, Brennan SC and Mun HC et al.. (2016) Structural mechanism of ligand activation in human calcium-sensing receptor. Elife 5 [PMID:27434672]

55. Gerbino A, Ruder WC, Curci S, Pozzan T, Zaccolo M and Hofer AM. (2005) Termination of cAMP signals by $\mathrm{Ca} 2+$ and $\mathrm{G}($ alpha)i via extracellular Ca2+ sensors: a link to intracellular Ca2+ oscillations. J Cell Biol 171: 303-12 [PMID:16247029]

56. Haden ST, Brown EM, Stoll AL, Scott J and Fuleihan GE. (1999) The effect of lithium on calciuminduced changes in adrenocorticotrophin levels. J Clin Endocrinol Metab 84: 198-200 [PMID:9920083]

57. Handlogten ME, Huang C, Shiraishi N, Awata H and Miller RT. (2001) The Ca2+-sensing receptor activates cytosolic phospholipase A2 via a Gqalpha -dependent ERK-independent pathway. J Biol Chem 276: 13941-8 [PMID:11278341]

58. Hannan FM, Babinsky VN and Thakker RV. (2016) Disorders of the calcium-sensing receptor and partner proteins: insights into the molecular basis of calcium homeostasis. J Mol Endocrinol 57: R127-42 [PMID:27647839]

59. Hatem S, Hoyaux D, De Decker V, Appelboom T, Pochet R and Steinfeld S. (2002) Expression of calcium-sensing receptor in human minor salivary glands. Clin Exp Rheumatol 20: 576-576 [PMID:12175122]

60. Hauache OM, Hu J, Ray K, Xie R, Jacobson KA and Spiegel AM. (2000) Effects of a calcimimetic compound and naturally activating mutations on the human $\mathrm{Ca} 2+$ receptor and on $\mathrm{Ca} 2+$ receptor/metabotropic glutamate chimeric receptors. Endocrinology 141: 4156-63 [PMID:11089548]

61. Ho C, Conner DA, Pollak MR, Ladd DJ, Kifor O, Warren HB, Brown EM, Seidman JG and Seidman CE. (1995) A mouse model of human familial hypocalciuric hypercalcemia and neonatal 
severe hyperparathyroidism. Nat Genet 11: 389-94 [PMID:7493018]

62. Huang C, Handlogten ME and Miller RT. (2002) Parallel activation of phosphatidylinositol 4kinase and phospholipase C by the extracellular calcium-sensing receptor. J Biol Chem 277: 20293-300 [PMID:11907035]

63. Huang C, Hujer KM, Wu Z and Miller RT. (2004) The Ca2+-sensing receptor couples to Galpha12/13 to activate phospholipase D in Madin-Darby canine kidney cells. Am J Physiol, Cell Physiol 286: C22-30 [PMID:12954603]

64. Itami A, Kato M, Komoto I, Doi R, Hosotani R, Shimada Y and Imamura M. (2001) Human gastrinoma cells express calcium-sensing receptor. Life Sci 70: 119-29 [PMID:11787938]

65. Janicic N, Soliman E, Pausova Z, Seldin MF, Rivière M, Szpirer J, Szpirer C and Hendy GN. (1995) Mapping of the calcium-sensing receptor gene (CASR) to human chromosome 3q13.3-21 by fluorescence in situ hybridization, and localization to rat chromosome 11 and mouse chromosome 16. Mamm Genome 6: 798-801 [PMID:8597637]

66. Kessler A, Faure H, Petrel C, Ruat M, Dauban P and Dodd RH. (2004) N2-benzyl-N1-(1-(1naphthyl)ethyl)-3-phenylpropane-1,2-diamines and conformationally restrained indole analogues: development of calindol as a new calcimimetic acting at the calcium sensing receptor. Bioorg Med Chem Lett 14: 3345-9 [PMID:15149704]

67. Kessler A, Faure H, Roussanne MC, Ferry S, Ruat M, Dauban P and Dodd RH. (2004) N(1)Arylsulfonyl-N(2)-(1-(1-naphthyl)ethyl)-1,2-diaminocyclohexanes: a new class of calcilytic agents acting at the calcium-sensing receptor. Chembiochem 5: 1131-6 [PMID:15300839]

68. Kiefer L, Leiris S and Dodd RH. (2011) Novel calcium sensing receptor ligands: a patent survey. Expert Opin Ther Pat 21: 681-98 [PMID:21406038]

69. Kifor O, Diaz R, Butters R and Brown EM. (1997) The Ca2+-sensing receptor (CaR) activates phospholipases C, A2, and D in bovine parathyroid and CaR-transfected, human embryonic kidney (HEK293) cells. J Bone Miner Res 12: 715-25 [PMID:9144337]

70. Kifor O, MacLeod RJ, Diaz R, Bai M, Yamaguchi T, Yao T, Kifor I and Brown EM. (2001) Regulation of MAP kinase by calcium-sensing receptor in bovine parathyroid and CaRtransfected HEK293 cells. Am J Physiol Renal Physiol 280: F291-F302 [PMID:11208605]

71. Komoto I, Kato M, Itami A, Shimada Y, Doi R, Hosotani R and Imamura M. (2003) Expression and function of the calcium-sensing receptor in pancreatic islets and insulinoma cells. Pancreas 26: 178-84 [PMID:12604917]

72. Komuves L, Oda Y, Tu CL, Chang WH, Ho-Pao CL, Mauro T and Bikle DD. (2002) Epidermal expression of the full-length extracellular calcium-sensing receptor is required for normal keratinocyte differentiation. J Cell Physiol 192: 45-54 [PMID:12115735]

73. Kumar S, Matheny CJ, Hoffman SJ, Marquis RW, Schultz M, Liang X, Vasko JA, Stroup GB, Vaden VR and Haley $\mathrm{H}$ et al.. (2010) An orally active calcium-sensing receptor antagonist that transiently increases plasma concentrations of PTH and stimulates bone formation. Bone 46: 534-42 [PMID:19786130]

74. Kwak JO, Kwak J, Kim HW, Oh KJ, Kim YT, Jung SM and Cha SH. (2005) The extracellular calcium sensing receptor is expressed in mouse mesangial cells and modulates cell proliferation. Exp Mol Med 37: 457-65 [PMID:16264270]

75. Kállay E, Bonner E, Wrba F, Thakker RV, Peterlik M and Cross HS. (2003) Molecular and functional characterization of the extracellular calcium-sensing receptor in human colon cancer cells. Oncol Res 13: 551-9 [PMID:12899245]

76. Leach K, Gregory KJ, Kufareva I, Khajehali E, Cook AE, Abagyan R, Conigrave AD, Sexton PM and Christopoulos A. (2016) Towards a structural understanding of allosteric drugs at the human calcium-sensing receptor. Cell Res 26: 574-92 [PMID:27002221]

77. Leach K, Hannan FM, Josephs TM, Keller AN, Møller TC, Ward DT, Kallay E, Mason RS, Thakker RV and Riccardi D et al.. (2020) International Union of Basic and Clinical Pharmacology. CVIII. Calcium-Sensing Receptor Nomenclature, Pharmacology, and Function. Pharmacol Rev 72: 558604 [PMID:32467152]

78. Leach K, Sexton PM, Christopoulos A and Conigrave AD. (2014) Engendering biased signalling from the calcium-sensing receptor for the pharmacotherapy of diverse disorders. Br J Pharmacol 171: 1142-55 [PMID:24111791]

79. Leach K, Wen A, Cook AE, Sexton PM, Conigrave AD and Christopoulos A. (2013) Impact of clinically relevant mutations on the pharmacoregulation and signaling bias of the calciumsensing receptor by positive and negative allosteric modulators. Endocrinology 154: 1105-16 [PMID:23372019]

80. Letz S, Haag C, Schulze E, Frank-Raue K, Raue F, Hofner B, Mayr B and Schöfl C. (2014) Amino alcohol- (NPS-2143) and quinazolinone-derived calcilytics (ATF936 and AXT914) differentially mitigate excessive signalling of calcium-sensing receptor mutants causing Bartter syndrome Type 5 and autosomal dominant hypocalcemia. PLoS ONE 9: e115178 [PMID:25506941]

81. Ma JN, Owens M, Gustafsson M, Jensen J, Tabatabaei A, Schmelzer K, Olsson R and Burstein ES. (2011) Characterization of highly efficacious allosteric agonists of the human calcium-sensing receptor. J Pharmacol Exp Ther 337: 275-84 [PMID:21239511] 
82. MacLeod RJ, Chattopadhyay N and Brown EM. (2003) PTHrP stimulated by the calcium-sensing receptor requires MAP kinase activation. Am J Physiol Endocrinol Metab 284: E435-42 [PMID:12388158]

83. MacLeod RJ, Yano S, Chattopadhyay N and Brown EM. (2004) Extracellular calcium-sensing receptor transactivates the epidermal growth factor receptor by a triple-membrane-spanning signaling mechanism. Biochem Biophys Res Commun 320: 455-60 [PMID:15219850]

84. Mamillapalli R and Wysolmerski J. (2010) The calcium-sensing receptor couples to Galpha(s) and regulates PTHrP and ACTH secretion in pituitary cells. J Endocrinol 204: 287-97 [PMID:20032198]

85. Mantovani G, Corbetta S, Romoli R, Alberti L, Beck-Peccoz P and Spada A. (2001) Absence of thyroid transcription factor-1 expression in human parathyroid and pituitary glands. Mol Cell Endocrinol 182: 13-7 [PMID:11500234]

86. McNeil L, Hobson S, Nipper V and Rodland KD. (1998) Functional calcium-sensing receptor expression in ovarian surface epithelial cells. Am J Obstet Gynecol 178: 305-13 [PMID:9500491]

87. McNeil SE, Hobson SA, Nipper V and Rodland KD. (1998) Functional calcium-sensing receptors in rat fibroblasts are required for activation of SRC kinase and mitogen-activated protein kinase in response to extracellular calcium. J Biol Chem 273: 1114-1120 [PMID:9422777]

88. Mitsuma T, Rhue N, Kayama M, Mori Y, Adachi K, Yokoi Y, Ping J, Nogimori T and Hirooka Y. (1999) Distribution of calcium sensing receptor in rats: an immunohistochemical study. Endocr Regul 33: 55-9 [PMID:10467425]

89. Miyazaki H, Ikeda Y, Sakurai O, Miyake T, Tsubota R, Okabe J, Kuroda M, Hisada Y, Yanagida T and Yoneda $\mathrm{H}$ et al.. (2018) Discovery of evocalcet, a next-generation calcium-sensing receptor agonist for the treatment of hyperparathyroidism. Bioorg Med Chem Lett 28: 2055-2060 [PMID:29724589]

90. Motoyama HI and Friedman PA. (2002) Calcium-sensing receptor regulation of PTH-dependent calcium absorption by mouse cortical ascending limbs. Am J Physiol Renal Physiol 283: F399406 [PMID:12167589]

91. Nagy E and Rigby WF. (1995) Glyceraldehyde-3-phosphate dehydrogenase selectively binds AUrich RNA in the NAD(+)-binding region (Rossmann fold). J Biol Chem 270: 2755-63 [PMID:7531693]

92. Nemeth EF. (2013) Allosteric modulators of the extracellular calcium receptor. Drug Discov Today Technol 10: e277-84 [PMID:24050279]

93. Nemeth EF. (2004) Calcimimetic and calcilytic drugs: just for parathyroid cells? Cell Calcium 35: 283-9 [PMID:15200152]

94. Nemeth EF, Delmar EG, Heaton WL, Miller MA, Lambert LD, Conklin RL, Gowen M, Gleason JG, Bhatnagar PK and Fox J. (2001) Calcilytic compounds: potent and selective Ca2+ receptor antagonists that stimulate secretion of parathyroid hormone. J Pharmacol Exp Ther 299: 323-31 [PMID:11561095]

95. Nemeth EF, Heaton WH, Miller M, Fox J, Balandrin MF, Van Wagenen BC, Colloton M, Karbon W, Scherrer J and Shatzen E et al.. (2004) Pharmacodynamics of the type II calcimimetic compound cinacalcet HCl. J Pharmacol Exp Ther 308: 627-35 [PMID:14593085]

96. Nemeth EF and Scarpa A. (1986) Cytosolic Ca2+ and the regulation of secretion in parathyroid cells. FEBS Lett 203: 15-19 [PMID:3755106]

97. Nemeth EF, Steffey ME, Hammerland LG, Hung BC, Van Wagenen BC, DelMar EG and Balandrin MF. (1998) Calcimimetics with potent and selective activity on the parathyroid calcium receptor. Proc Natl Acad Sci USA 95: 4040-5 [PMID:9520489]

98. Oda Y, Tu CL, Chang W, Crumrine D, Kömüves L, Mauro T, Elias PM and Bikle DD. (2000) The calcium sensing receptor and its alternatively spliced form in murine epidermal differentiation. $J$ Biol Chem 275: 1183-90 [PMID:10625662]

99. Oda Y, Tu CL, Pillai S and Bikle DD. (1998) The calcium sensing receptor and its alternatively spliced form in keratinocyte differentiation. J Biol Chem 273: 23344-52 [PMID:9722568]

100. Ogata S, Kubota Y, Satoh S, Ito S, Takeuchi H, Ashizuka M and Shirasuna K. (2006) Ca2+ stimulates COX-2 expression through calcium-sensing receptor in fibroblasts. Biochem Biophys Res Commun 351: 808-14 [PMID:17097611]

101. Ohsu T, Amino Y, Nagasaki H, Yamanaka T, Takeshita S, Hatanaka T, Maruyama Y, Miyamura N and Eto Y. (2010) Involvement of the calcium-sensing receptor in human taste perception. J Biol Chem 285: 1016-22 [PMID:19892707]

102. Olszak IT, Poznansky MC, Evans RH, Olson D, Kos C, Pollak MR, Brown EM and Scadden DT. (2000) Extracellular calcium elicits a chemokinetic response from monocytes in vitro and in vivo. J Clin Invest 105: 1299-305 [PMID:10792005]

103. Peiris D, Pacheco I, Spencer C and MacLeod RJ. (2007) The extracellular calcium-sensing receptor reciprocally regulates the secretion of BMP-2 and the BMP antagonist Noggin in colonic myofibroblasts. Am J Physiol Gastrointest Liver Physiol 292: G753-66 [PMID:17138967]

104. Petrel C, Kessler A, Dauban P, Dodd RH, Rognan D and Ruat M. (2004) Positive and negative allosteric modulators of the Ca2+-sensing receptor interact within overlapping but not identical 
binding sites in the transmembrane domain. J Biol Chem 279: 18990-7 [PMID:14976203]

105. Petrel C, Kessler A, Maslah F, Dauban P, Dodd RH, Rognan D and Ruat M. (2003) Modeling and mutagenesis of the binding site of Calhex 231, a novel negative allosteric modulator of the extracellular $\mathrm{Ca}(2+)$-sensing receptor. J Biol Chem 278: 49487-94 [PMID:14506236]

106. Pi M, Faber P, Ekema G, Jackson PD, Ting A, Wang N, Fontilla-Poole M, Mays RW, Brunden KR and Harrington JJ et al.. (2005) Identification of a novel extracellular cation-sensing G-proteincoupled receptor. J Biol Chem 280: 40201-9 [PMID:16199532]

107. Pi M, Spurney RF, Tu Q, Hinson T and Quarles LD. (2002) Calcium-sensing receptor activation of rho involves filamin and rho-guanine nucleotide exchange factor. Endocrinology 143: 3830-8 [PMID:12239094]

108. Quinn SJ, Bai M and Brown EM. (2004) pH Sensing by the calcium-sensing receptor. J Biol Chem 279: 37241-9 [PMID:15201280]

109. Quinn SJ, Kifor O, Trivedi S, Diaz R, Vassilev P and Brown E. (1998) Sodium and ionic strength sensing by the calcium receptor. J Biol Chem 273: 19579-86 [PMID:9677383]

110. Quinn SJ, Ye CP, Diaz R, Kifor O, Bai M, Vassilev P and Brown E. (1997) The Ca2+-sensing receptor: a target for polyamines. Am J Physiol 273: C1315-23 [PMID:9357776]

111. Remy C, Kirchhoff P, Hafner P, Busque SM, Müeller MK, Geibel JP and Wagner CA. (2007) Stimulatory pathways of the Calcium-sensing receptor on acid secretion in freshly isolated human gastric glands. Cell Physiol Biochem 19: 33-42 [PMID:17310098]

112. Riccardi D, Hall AE, Chattopadhyay N, Xu JZ, Brown EM and Hebert SC. (1998) Localization of the extracellular $\mathrm{Ca} 2+/$ polyvalent cation-sensing protein in rat kidney. Am J Physiol 274: F61122 [PMID:9530279]

113. Riccardi D, Park J, Lee WS, Gamba G, Brown EM and Hebert SC. (1995) Cloning and functional expression of a rat kidney extracellular calcium/polyvalent cation-sensing receptor. Proc Natl Acad Sci USA 92: 131-5 [PMID:7816802]

114. Riccardi D, Traebert M, Ward DT, Kaissling B, Biber J, Hebert SC and Murer H. (2000) Dietary phosphate and parathyroid hormone alter the expression of the calcium-sensing receptor (CaR) and the $\mathrm{Na}+$-dependent $\mathrm{Pi}$ transporter (NaPi-2) in the rat proximal tubule. Pflugers Arch 441: 379-387 [PMID:11211126]

115. Rodriguez L, Tu C, Cheng Z, Chen TH, Bikle D, Shoback D and Chang W. (2005) Expression and functional assessment of an alternatively spliced extracellular Ca2+-sensing receptor in growth plate chondrocytes. Endocrinology 146: 5294-303 [PMID:16166224]

116. Rogers KV, Dunn CK, Hebert SC and Brown EM. (1997) Localization of calcium receptor mRNA in the adult rat central nervous system by in situ hybridization. Brain Res 744: 47-56 [PMID:9030412]

117. Rutten MJ, Bacon KD, Marlink KL, Stoney M, Meichsner CL, Lee FP, Hobson SA, Rodland KD, Sheppard BC and Trunkey DD et al.. (1999) Identification of a functional Ca2+-sensing receptor in normal human gastric mucous epithelial cells. Am J Physiol 277: G662-70 [PMID:10484392]

118. Rácz GZ, Kittel A, Riccardi D, Case RM, Elliott AC and Varga G. (2002) Extracellular calcium sensing receptor in human pancreatic cells. Gut 51: 705-11 [PMID:12377811]

119. Sanders JL, Chattopadhyay N, Kifor O, Yamaguchi T and Brown EM. (2000) Extracellular calcium-sensing receptor (CaR) expression and its potential role in parathyroid hormone-related peptide (PTHrP) secretion in the H-500 rat Leydig cell model of humoral hypercalcemia of malignancy. Biochem Biophys Res Commun 269: 427-32 [PMID:10708570]

120. Sanders JL, Chattopadhyay N, Kifor O, Yamaguchi T and Brown EM. (2001) Ca(2+)-sensing receptor expression and PTHrP secretion in PC-3 human prostate cancer cells. Am J Physiol Endocrinol Metab 281: E1267-74 [PMID:11701443]

121. Sanders JL, Chattopadhyay N, Kifor O, Yamaguchi T, Butters RR and Brown EM. (2000) Extracellular calcium-sensing receptor expression and its potential role in regulating parathyroid hormone-related peptide secretion in human breast cancer cell lines. Endocrinology 141: 4357-4364 [PMID:11108243]

122. Sands JM, Naruse M, Baum M, Jo I, Hebert SC, Brown EM and Harris HW. (1997) Apical extracellular calcium/polyvalent cation-sensing receptor regulates vasopressin-elicited water permeability in rat kidney inner medullary collecting duct. J Clin Invest 99: 1399-1405 [PMID:9077550]

123. Shalhoub V, Grisanti M, Padagas J, Scully S, Rattan A, Qi M, Varnum B, Vezina C, Lacey D and Martin D. (2003) In vitro studies with the calcimimetic, cinacalcet $\mathrm{HCl}$, on normal human adult osteoblastic and osteoclastic cells. Crit Rev Eukaryot Gene Expr 13: 89-106 [PMID:14696958]

124. Shcherbakova I, Huang G, Geoffroy OJ, Nair SK, Swierczek K, Balandrin MF, Fox J, Heaton WL and Conklin RL. (2005) Design, new synthesis, and calcilytic activity of substituted 3Hpyrimidin-4-ones. Bioorg Med Chem Lett 15: 2537-40 [PMID:15863312]

125. Sheinin Y, Kállay E, Wrba F, Kriwanek S, Peterlik M and Cross HS. (2000) Immunocytochemical localization of the extracellular calcium-sensing receptor in normal and malignant human large intestinal mucosa. J Histochem Cytochem 48: 595-602 [PMID:10769043]

126. Shinagawa $Y$, Inoue T, Katsushima T, Kiguchi T, Ikenogami T, Ogawa N, Fukuda K, Hirata K, 
Harada K and Takagi M et al.. (2011) Discovery of a potent and short-acting oral calcilytic with a pulsatile secretion of parathyroid hormone. ACS Med Chem Lett 2: 238-42 [PMID:24900301]

127. Tfelt-Hansen J, Chattopadhyay N, Yano S, Kanuparthi D, Rooney P, Schwarz P and Brown EM. (2004) Calcium-sensing receptor induces proliferation through p38 mitogen-activated protein kinase and phosphatidylinositol 3-kinase but not extracellularly regulated kinase in a model of humoral hypercalcemia of malignancy. Endocrinology 145: 1211-7 [PMID:14645111]

128. Thomsen AR, Hvidtfeldt $M$ and Bräuner-Osborne H. (2012) Biased agonism of the calciumsensing receptor. Cell Calcium 51: 107-16 [PMID:22192592]

129. Turksen K and Troy TC. (2003) Overexpression of the calcium sensing receptor accelerates epidermal differentiation and permeability barrier formation in vivo. Mech Dev 120: 733-44 [PMID:12834872]

130. VanHouten J, Dann P, McGeoch G, Brown EM, Krapcho K, Neville M and Wysolmerski JJ. (2004) The calcium-sensing receptor regulates mammary gland parathyroid hormone-related protein production and calcium transport. J Clin Invest 113: 598-608 [PMID:14966569]

131. Wada M, Nagano N, Furuya Y, Chin J, Nemeth EF and Fox J. (2000) Calcimimetic NPS R-568 prevents parathyroid hyperplasia in rats with severe secondary hyperparathyroidism. Kidney Int 57: 50-8 [PMID:10620187]

132. Walter S, Baruch A, Dong J, Tomlinson JE, Alexander ST, Janes J, Hunter T, Yin Q, Maclean D and Bell G et al.. (2013) Pharmacology of AMG 416 (Velcalcetide), a novel peptide agonist of the calcium-sensing receptor, for the treatment of secondary hyperparathyroidism in hemodialysis patients. J Pharmacol Exp Ther 346: 229-40 [PMID:23674604]

133. Wang M, Yao Y, Kuang D and Hampson DR. (2006) Activation of family C G-protein-coupled receptors by the tripeptide glutathione. J Biol Chem 281: 8864-70 [PMID:16455645]

134. Wang R, Xu C, Zhao W, Zhang J, Cao K, Yang B and Wu L. (2003) Calcium and polyamine regulated calcium-sensing receptors in cardiac tissues. Eur J Biochem 270: 2680-8 [PMID:12787035]

135. Wang Y, Awumey EK, Chatterjee PK, Somasundaram C, Bian K, Rogers KV, Dunn C and Bukoski RD. (2003) Molecular cloning and characterization of a rat sensory nerve Ca2+-sensing receptor. Am J Physiol Cell Physiol 285: C64-C75 [PMID:12637267]

136. Ward DT and Riccardi D. (2012) New concepts in calcium-sensing receptor pharmacology and signalling. Br J Pharmacol 165: 35-48 [PMID:21627634]

137. Widler L, Altmann E, Beerli R, Breitenstein W, Bouhelal R, Buhl T, Gamse R, Gerspacher M, Halleux C and John MR et al.. (2010) 1-Alkyl-4-phenyl-6-alkoxy-1H-quinazolin-2-ones: a novel series of potent calcium-sensing receptor antagonists. J Med Chem 53: 2250-63 [PMID:20158186]

138. Yamaguchi T, Chattopadhyay N, Kifor O and Brown EM. (1998) Extracellular calcium (Ca2+(o))sensing receptor in a murine bone marrow-derived stromal cell line (ST2): potential mediator of the actions of $\mathrm{Ca} 2+(\mathrm{o})$ on the function of ST2 cells. Endocrinology 139: 3561-8 [PMID:9681508]

139. Yamaguchi T, Chattopadhyay N, Kifor O, Butters Jr RR, Sugimoto T and Brown EM. (1998) Mouse osteoblastic cell line (MC3T3-E1) expresses extracellular calcium (Ca2+o)-sensing receptor and its agonists stimulate chemotaxis and proliferation of MC3T3-E1 cells. J Bone Miner Res 13: 1530-8 [PMID:9783541]

140. Yamaguchi T, Chattopadhyay N, Kifor O, Ye C, Vassilev PM, Sanders JL and Brown EM. (2001) Expression of extracellular calcium-sensing receptor in human osteoblastic MG-63 cell line. Am J Physiol, Cell Physiol 280: C382-93 [PMID:11208534]

141. Yamaguchi T, Yamauchi M, Sugimoto T, Chauhan D, Anderson KC, Brown EM and Chihara K. (2002) The extracellular calcium Ca2+o-sensing receptor is expressed in myeloma cells and modulates cell proliferation. Biochem Biophys Res Commun 299: 532-8 [PMID:12459170]

142. Yamaguchi T, Ye C, Chattopadhyay N, Sanders JL, Vassilev PM and Brown EM. (2000) Enhanced expression of extracellular calcium sensing receptor in monocyte-differentiated versus undifferentiated HL-60 cells: potential role in regulation of a nonselective cation channel. Calcif Tissue Int 66: 375-82 [PMID:10773108]

143. Yang W, Ruan Z, Wang Y, Van Kirk K, Ma Z, Arey BJ, Cooper CB, Seethala R, Feyen JH and Dickson Jr JK. (2009) Discovery and structure-activity relationships of trisubstituted pyrimidines/pyridines as novel calcium-sensing receptor antagonists. J Med Chem 52: 1204-8 [PMID:19143533]

144. Yang W, Wang Y, Roberge JY, Ma Z, Liu Y, Michael Lawrence R, Rotella DP, Seethala R, Feyen JH and Dickson Jr JK. (2005) Discovery and structure-activity relationships of 2-

benzylpyrrolidine-substituted aryloxypropanols as calcium-sensing receptor antagonists. Bioorg Med Chem Lett 15: 1225-8 [PMID:15686947]

145. Yano S, Macleod RJ, Chattopadhyay N, Tfelt-Hansen J, Kifor O, Butters RR and Brown EM. (2004) Calcium-sensing receptor activation stimulates parathyroid hormone-related protein secretion in prostate cancer cells: role of epidermal growth factor receptor transactivation. Bone 35: 664-72 [PMID:15336602]

146. Ye C, Chattopadhyay N, Brown EM and Vassilev PM. (2000) Defective extracellular calcium 
$(\mathrm{Ca}(\mathrm{o}))$-sensing receptor $(\mathrm{CaR})$-mediated stimulation of a $\mathrm{Ca}(2+)$-activated potassium channel in glioblastoma cells transfected with a dominant negative CaR. Brain Res Mol Brain Res 80: 177187 [PMID:11038250]

147. Ye C, Rogers K, Bai M, Quinn SJ, Brown EM and Vassilev PM. (1996) Agonists of the Ca(2+)sensing receptor ( $\mathrm{CaR}$ ) activate nonselective cation channels in HEK293 cells stably transfected with the human CaR. Biochem Biophys Res Commun 226: 572-9 [PMID:8806675]

148. Zhang C, Miller CL, Gorkhali R, Zou J, Huang K, Brown EM and Yang JJ. (2016) Molecular Basis of the Extracellular Ligands Mediated Signaling by the Calcium Sensing Receptor. Front Physiol 7: 441 [PMID:27746744] 